\title{
Synthesis of Homopolymer Containing Diphenyl End-capped Oligothiophene Co-oligomer Unit in the Side Chain
}

\author{
Chunchang Zhao, ${ }^{\dagger}$ Yong Zhang, ${ }^{\dagger}$ Chengwei Wang, ${ }^{\dagger}$ Lewis Rothberg, ${ }^{\dagger,}$ Man-Kit Ng*, \\ ${ }^{\dagger}$ Department of Chemistry, University of Rochester, Rochester, New York 14627, and \\ ${ }^{*}$ Department of Chemical Engineering, University of Rochester, Rochester, New York 14627 \\ ng@chem.rochester.edu
}

\section{Experimental Section}

General. All chemicals were purchased from Aldrich Chemical Co. unless otherwise specified. Anhydrous $\mathrm{N}, \mathrm{N}$-dimethylformamide (DMF)), chloroform and acetic acid were used as received without further purification. Tetrahydrofuran (THF), dichloromethane, toluene and diethyl ether were dried and distillated immediately prior to use. 2 -(Tributylstannyl)thiophene, ${ }^{1}$ 3-(tributylstannyl)thiophene, ${ }^{1}$ and 2-iodo-1,4-dimethoxylbenzene ${ }^{2}$ were prepared according to literature procedures.

${ }^{1} \mathrm{H}$ NMR and ${ }^{13} \mathrm{C}$ NMR spectra were recorded on a Brüker Avance 400 FT-NMR spectrometer operating at $400 \mathrm{MHz}$ and $100 \mathrm{MHz}$, respectively. Deuterated chloroform was used as the solvent. Weight-averaged molecular weight $\left(M_{\mathrm{w}}\right)$ and number-averaged molecular weight $\left(M_{\mathrm{n}}\right)$ were determined by gel permeation chromatography (GPC) using a Agilent mode 1100 HPLC system equipped with ViscoGEL ${ }^{\mathrm{TM}}$ columns using polystyrene as the standard and THF as the eluent. Thermogravimetric analysis (TGA) was performed on a TA Instruments (SDT Q600 thermogravimetric analyzer) module at a heating rate of $10{ }^{\circ} \mathrm{C} \min ^{-1}$ under a nitrogen atmosphere. The temperature regime was from room temperature to $600{ }^{\circ} \mathrm{C}$. Polymer solution was prepared in anhydrous spectrum-grade chloroform and polymer thin film was deposited onto glass plates by spin-coating. The absorption and fluorescence spectral measurements of polymer solutions and thin films were conducted on a Shimadzu UV-2401 PC UV-vis spectrophotometer and on a Fluorolog-3 spectrofluorometer, respectively.

3-(2,5-dimethoxyphenyl)thiophene (1). 3-(Tributylstannyl)thiophene (12.0 g, $32.2 \mathrm{mmol})$ and 2-iodo-1,4-dimethoxylbenzene $(8.45 \mathrm{~g}, 32.0 \mathrm{mmol})$ were dissolved in anhydrous DMF under $\mathrm{N}_{2}$ and purged with $\mathrm{N}_{2}$ for 30 min. A mixture of $\mathrm{Pd}\left(\mathrm{PPh}_{3}\right)_{2} \mathrm{Cl}_{2}(133 \mathrm{mg}, 0.189 \mathrm{mmol})$ and $\mathrm{PPh}_{3}$ 
(99 mg, $0.38 \mathrm{mmol}$ ) were added in one portion. The resulting mixture was heated to $100{ }^{\circ} \mathrm{C}$ overnight and cooled to room temperature. Excess DMF was removed under high vacuum and to the residue was added $10 \%$ aqueous KF. The mixture was filtered through a pad of Celite. The filtrate was dried over $\mathrm{Na}_{2} \mathrm{SO}_{4}$, filtered, and the solvent was removed in vacuo. The crude product was purified by flash chromatography (silica gel) to afford $5.20 \mathrm{~g}(23.6 \mathrm{mmol}, 74 \%)$ of $\mathbf{1}$. ${ }^{1} \mathrm{H}$ NMR (400 MHz, $\left.\mathrm{CDCl}_{3}\right) \delta 7.63(\mathrm{dd}, 1 \mathrm{H}), 7.44(\mathrm{dd}, 1 \mathrm{H}), 7.35$ (m, 1H), 7.07(d, 1H), 6.91 (d, $1 \mathrm{H}), 6.82(\mathrm{dd}, 1 \mathrm{H}), 3.82(\mathrm{~s}, 3 \mathrm{H}), 3.81(\mathrm{~s}, 3 \mathrm{H})$; LRMS $\left(\mathrm{APCI}^{+}\right)$calcd for $\mathrm{C}_{12} \mathrm{H}_{12} \mathrm{O}_{2} \mathrm{~S}: 220.06$. Found: $221.0[\mathrm{M}+\mathrm{H}]^{+}$.

2-Iodo-3-(2,5-dimethoxyphenyl)thiophene (2). To a solution of $\mathbf{1}$ (4.47 g, $20.3 \mathrm{mmol})$ in a mixture of $\mathrm{AcOH} / \mathrm{CHCl}_{3}$ was added $\mathrm{N}$-iodosuccinimide (NIS) (4.62 g, $20.5 \mathrm{mmol}$ ) in small portions. The mixture was stirred at room temperature for $5 \mathrm{~h}$ and then poured into water and extracted with ether. The combined organic layers were washed with saturated $\mathrm{NaHCO}_{3}$, $\mathrm{Na}_{2} \mathrm{~S}_{2} \mathrm{O}_{3}$, water, and dried over anhydrous $\mathrm{Na}_{2} \mathrm{SO}_{4}$. The solvent was removed in vacuo to afford $7.0 \mathrm{~g}$ (20.2 mmol, 99.5\%) of 2 , which was pure enough for the next step. ${ }^{1} \mathrm{H} \mathrm{NMR}(400 \mathrm{MHz}$, $\left.\mathrm{CDCl}_{3}\right) \delta 7.46(\mathrm{~d}, 1 \mathrm{H}), 6.95(\mathrm{~d}, 1 \mathrm{H}), 6.90(\mathrm{~m}, 2 \mathrm{H}), 6.87(\mathrm{~m}, 1 \mathrm{H}), 3.81(\mathrm{~s}, 3 \mathrm{H}), 3.75(\mathrm{~s}, 3 \mathrm{H})$; LRMS (APCI ${ }^{+}$) calcd for $\mathrm{C}_{12} \mathrm{H}_{11} \mathrm{IO}_{2} \mathrm{~S}: 345.95$. Found: $345.9[\mathrm{M}]^{+}$.

3-(2,5-dimethoxyphenyl)-2,2'-bithiophene (3). 2-(Tributylstannyl)thiophene (4.14 g, 11.1 mmol) was added to a solution of $2(3.19 \mathrm{~g}, 9.2 \mathrm{mmol})$ in anhydrous DMF, and the resulting mixture was purged with $\mathrm{N}_{2}$ for $30 \mathrm{~min}$. A mixture of $\mathrm{Pd}\left(\mathrm{PPh}_{3}\right)_{2} \mathrm{Cl}_{2}(48 \mathrm{mg}, 0.068 \mathrm{mmol})$ and $\mathrm{PPh}_{3}(36 \mathrm{mg}, 0.136 \mathrm{mmol})$ were then added and the reaction mixture was heated to $100{ }^{\circ} \mathrm{C}$ overnight. Excess DMF was removed under high vacuum and to the residue was added $10 \%$ aqueous KF. The mixture was filtered through a pad of Celite. The filtrate was dried over $\mathrm{Na}_{2} \mathrm{SO}_{4}$, filtered, and the solvent was removed in vacuo. The crude product was purified by flash chromatography (silica gel) to afford $1.95 \mathrm{~g}(6.45 \mathrm{mmol}, 70 \%)$ of 3 . ${ }^{1} \mathrm{H} \mathrm{NMR}(400 \mathrm{MHz}$, $\left.\mathrm{CDCl}_{3}\right) \delta 7.24(\mathrm{~d}, 1 \mathrm{H}), 7.12(\mathrm{dd}, 1 \mathrm{H}), 7.04(\mathrm{~d}, 1 \mathrm{H}), 6.78(\mathrm{dd}, 1 \mathrm{H}), 6.88(\mathrm{~m}, 1 \mathrm{H}), 6.87(\mathrm{~m}, 2 \mathrm{H})$, $6.80 \mathrm{~m}, 1 \mathrm{H}), 3.72(\mathrm{~s}, \mathrm{H}), 3.62(\mathrm{~s}, 3 \mathrm{H}) ;{ }^{13} \mathrm{C} \mathrm{NMR}\left(100 \mathrm{MHz}, \mathrm{CDCl}_{3}\right) \delta 153.55,151.66,136.54$, $134.71,133.06,131.08,126.85,126.23,125.46,125.17,123.06,117.13,114.26,112.70,56.13$, 55.70; HRMS (ESI) calcd for $\mathrm{C}_{16} \mathrm{H}_{14} \mathrm{O}_{2} \mathrm{~S}_{2}: 302.0435$. Found: $303.0505[\mathrm{M}+\mathrm{H}]^{+}$.

3-(2,5-dimethoxyphenyl)-5,5'-diiodo-2,2'-bithiophene (4). NIS (1.89 g, $8.4 \mathrm{mmol})$ was added, in small portions, to a solution of $3(1.22 \mathrm{~g}, 4.03 \mathrm{mmol})$ in a mixture of $\mathrm{AcOH} / \mathrm{CHCl}_{3}$. The mixture was stirred at room temperature for $7 \mathrm{~h}$ and then poured into water and extracted 
with $\mathrm{CH}_{2} \mathrm{Cl}_{2}$. The combined organic layers were washed with saturated $\mathrm{NaHCO}_{3}, \mathrm{Na}_{2} \mathrm{~S}_{2} \mathrm{O}_{3}$, water, and dried over anhydrous $\mathrm{Na}_{2} \mathrm{SO}_{4}$. The solvent was removed in vacuo to afford $2.23 \mathrm{~g}$ (4.02 mmol, 99.75) of $\mathbf{4}$, which was pure enough for next step. ${ }^{1} \mathrm{H}$ NMR (400 $\mathrm{MHz}, \mathrm{CDCl}_{3}$ ) $\delta 7.13(\mathrm{~s}, 1 \mathrm{H}), 7.03(\mathrm{~d}, 1 \mathrm{H}), 6.89(\mathrm{~d}, 1 \mathrm{H}), 6.87(\mathrm{~s}, 1 \mathrm{H}), 6.72(\mathrm{~d}, 1 \mathrm{H}), 6.63(\mathrm{~d}, 1 \mathrm{H}), 3.73(\mathrm{~s}, 3 \mathrm{H})$, $3.64(\mathrm{~s}, 3 \mathrm{H})$; LRMS $\left(\mathrm{APCI}^{+}\right)$calcd for $\mathrm{C}_{16} \mathrm{H}_{12} \mathrm{I}_{2} \mathrm{O}_{2} \mathrm{~S}_{2}: 553.84$. Found: $553.7[\mathrm{M}]^{+}$.

\section{4'-(2,5-dimethoxyphenyl)-5,5','-diphenyl-2,2';5',2';5',2','-quaterthiophene (5). A}

solution of 4 (1.22 g, $2.20 \mathrm{mmol})$ and 2-(tributylstannyl)-5-phenylthiophene (2.47 g, $5.50 \mathrm{mmol})$ in anhydrous DMF was purged with $\mathrm{N}_{2}$ for $30 \mathrm{~min}$. A mixture of $\mathrm{Pd}\left(\mathrm{PPh}_{3}\right)_{2} \mathrm{Cl}_{2}(77 \mathrm{mg}, 0.11$ $\mathrm{mmol})$ and $\mathrm{PPh}_{3}(58 \mathrm{mg}, 0.22 \mathrm{mmol}$ ) were then added. The resulting mixture was heated to 100 ${ }^{\circ} \mathrm{C}$ overnight, cooled to room temperature, and filtered. The solvent was removed under high vacuum and ether was added to the residue. The slurry was stirred for $30 \mathrm{~min}$, filtered, and the solid was washed with ether. The solid was subsequently transferred to a flask, and ethyl acetate was added, the slurry was stirred for $30 \mathrm{~min}$, filtered, and the solid was washed with ethyl acetate. This procedure was repeated three times to afford $1.02 \mathrm{~g}(1.65 \mathrm{mmol}, 75 \%)$ of $\mathbf{5}$. ${ }^{1} \mathrm{H}$ NMR (400 MHz, $\left.\mathrm{CDCl}_{3}\right) \delta 7.59(\mathrm{~m}, 4 \mathrm{H}), 7.38(\mathrm{~m}, 4 \mathrm{H}), 7.29(\mathrm{~m}, 2 \mathrm{H}), 7.25(\mathrm{~d}, 1 \mathrm{H}), 7.18(\mathrm{~m}, 2 \mathrm{H}), 7.13(\mathrm{~s}$, 1H), $7.02(\mathrm{~d}, 1 \mathrm{H}), 6.99(\mathrm{~d}, 1 \mathrm{H}), 6.93(\mathrm{~m}, 2 \mathrm{H}), 6.89(\mathrm{~m}, 2 \mathrm{H}), 3.78(\mathrm{~s}, 3 \mathrm{H}), 3.69(\mathrm{~s}, 3 \mathrm{H}) ;{ }^{13} \mathrm{C}$ NMR $\left(100 \mathrm{MHz}, \mathrm{CDCl}_{3}\right) \delta 153.61,151.46,143.27,143.06,136.86,136.47,136.23,135.35,135.22$, 134.63 , 133.96, 133.95, 131.64, 128.90, 128.88, 127.56, 125.92, 125.56, 124.61, 124.37, 123.78, 123.68, 123.55, 116.73, 115.00, 112.69, 56.17, 55.80; HRMS (ESI) calcd for $\mathrm{C}_{36} \mathrm{H}_{26} \mathrm{O}_{2} \mathrm{~S}_{4}$ : 618.0186. Found: $618.0829[\mathrm{M}]^{+}$.

4'-(2,5-benzoquinonyl)-5,5','-diphenyl-2,2';5',2',;5',2','-quaterthiophene (6). A solution of 5 (300 mg, $0.485 \mathrm{mmol})$ in dry $\mathrm{CH}_{2} \mathrm{Cl}_{2}$ was cooled to $-78{ }^{\circ} \mathrm{C}$, and a solution of $\mathrm{BBr}_{3}$ in $\mathrm{CH}_{2} \mathrm{Cl}_{2}$ (1.0 M, $7.28 \mathrm{ml}, 15$ equiv.) was added dropwise from a syringe. The mixture was stirred at $-78{ }^{\circ} \mathrm{C}$ for $1 \mathrm{~h}$ and then slowly warmed to room temperature and stirred at room temperature overnight. The mixture was cooled to $0{ }^{\circ} \mathrm{C}$, and water was added to hydrolyze the excess $\mathrm{BBr}_{3}$. The mixture was washed with water and the separated organic layer was dried over anhydrous $\mathrm{Na}_{2} \mathrm{SO}_{4}$, and filtered. A mixture of $\mathrm{Na}_{2} \mathrm{SO}_{4}$ and $\mathrm{Ag}_{2} \mathrm{O}$ was then added to the filtrate, and the heterogeneous mixture was stirred at room temperature for $5 \mathrm{~h}$. After filtering and removal of the volatiles, the residue was purified by flash chromatography (silica gel) to afford $186 \mathrm{mg}(0.316 \mathrm{mmol}, 65 \%)$ of 6. ${ }^{1} \mathrm{H} \mathrm{NMR}\left(400 \mathrm{MHz}, \mathrm{CDCl}_{3}\right) \delta 7.61(\mathrm{~m}, 4 \mathrm{H}), 7.40(\mathrm{~m}, 4 \mathrm{H})$, $7.29(\mathrm{~m}, 2 \mathrm{H}), 7.25(\mathrm{~d}, 1 \mathrm{H}), 7.22(\mathrm{~d}, 1 \mathrm{H}), 7.19(\mathrm{~d}, 1 \mathrm{H}), 7.11(\mathrm{~d}, 1 \mathrm{H}), 7.10(\mathrm{~s}, 1 \mathrm{H}), 7.09(\mathrm{~d}, 1 \mathrm{H})$, 
$7.02(\mathrm{~d}, 1 \mathrm{H}), 6.93(\mathrm{~d}, 1 \mathrm{H}), 6.88(\mathrm{~s}, 1 \mathrm{H}), 6.87(\mathrm{~d}, 1 \mathrm{H}) ;{ }^{13} \mathrm{C}$ NMR $\left(100 \mathrm{MHz}, \mathrm{CDCl}_{3}\right) \delta$ 187.07, 185.49, 144.18, 143.83, 142.61, 138.84, 136.96, 136.62, 136.52, 135.67, 135.09, 135.03, 134.60, $133.78,133.72,133.09,130.21,128.96,128.92,127.83,127.77,127.72,126.03,125.65,125.61$, 125.34, 125.01, 124.05, 123.86, 123.77; HRMS (ESI) calcd for $\mathrm{C}_{34} \mathrm{H}_{20} \mathrm{O}_{2} \mathrm{~S}_{4}$ : 588.0346. Found: $588.0358[\mathrm{M}]^{+}$.

\section{4'-(1,4,9,10-Tetrahydro-2,4-methano-naphthalene-5,8-dione-6-yl)-5,5'"-diphenyl-}

2,2';5',2";5",2"'-quaterthiophene (7). A mixture of 6 (100 mg, $0.170 \mathrm{mmol})$ and dcyclopentadiene (56 mg, $0.85 \mathrm{mmol}, 5$ equiv.) in $\mathrm{CH}_{2} \mathrm{Cl}_{2}$ were stirred at room temperature overnight. The solvent was removed in vacuo and the residual solid was washed with hexane several times to afford $110 \mathrm{mg}(0.168 \mathrm{mmol}, 99 \%)$ of $7 .{ }^{1} \mathrm{H}$ NMR $\left(400 \mathrm{MHz}, \mathrm{CDCl}_{3}\right) \delta 7.60(\mathrm{~d}$, 4H), 7.39 (t, 4H), $7.31(\mathrm{~m}, 2 \mathrm{H}), 7.24(\mathrm{t}, 2 \mathrm{H}), 7.16(\mathrm{~d}, 1 \mathrm{H}), 7.12(\mathrm{~d}, 1 \mathrm{H}), 7.09(\mathrm{~d}, 1 \mathrm{H}), 7.03(\mathrm{~s}, 1 \mathrm{H})$, $6.98(\mathrm{~d}, 1 \mathrm{H}), 6.75(\mathrm{~s}, 1 \mathrm{H}), 6.17(\mathrm{~m}, 2 \mathrm{H}), 3.61(\mathrm{~s}, 2 \mathrm{H}), 3.38(\mathrm{t}, 2 \mathrm{H}), 1.57(\mathrm{~d}, 1 \mathrm{H}), 1.47(\mathrm{~d}, 1 \mathrm{H}),{ }^{13} \mathrm{C}$ NMR $\left(100 \mathrm{MHz}, \mathrm{CDCl}_{3}\right) \delta 198.77,197.44,147.59,144.09,143.81,141.09,138.70,136.41$, $135.85,135.80,135.66,135.15,134.11,133.82$, 133.79, 133.01, 131.17, 128.92, 127.86, 127.76, $127.72,126.08,125.63,125.25,124.87,123.89,123.81,49.39,49.28,48.63,48.46$; HRMS (ESI) calcd for $\mathrm{C}_{39} \mathrm{H}_{26} \mathrm{O}_{2} \mathrm{~S}_{4}: 654.0816$. Found: $654.0837[\mathrm{M}]^{+}$.

\section{4'-(1,4-Dihydro-5,8-dimethoxy-1,4-methano-naphthalen-6-yl)-5,5"'-diphenyl-}

2,2';5',2';5',2"'-quaterthiophene (8). A solution of 7 (100 mg, $0.153 \mathrm{mmol})$ in DMF was cooled to $-15{ }^{\circ} \mathrm{C}$ and $\mathrm{NaH}(37 \mathrm{mg}, 0.93 \mathrm{mmol}, 60 \% \mathrm{w} / \mathrm{w}$ in mineral oil) was added. The mixture was stirred at $-15^{\circ} \mathrm{C}$ for $1 \mathrm{~h}$, and $\mathrm{Me}_{2} \mathrm{SO}_{4}(192 \mathrm{mg}, 1.5 \mathrm{mmol})$ was added. The cooling apparatus was removed, and the solution was warmed to room temperature over $3 \mathrm{~h}$. The reaction was quenched with dilute $\mathrm{NH}_{4} \mathrm{Cl}$ and extracted with $\mathrm{CH}_{2} \mathrm{Cl}_{2}$. The combined organic extracts were washed with dilute $\mathrm{NH}_{4} \mathrm{Cl}$ and saturated $\mathrm{NaCl}$ and dried over anhydrous $\mathrm{Na}_{2} \mathrm{SO}_{4}$. After filtration, the solvent was removed in vacuo and the resulting solid was purified by flash chromatography to afford $52 \mathrm{mg}(0.076 \mathrm{mmol}, 50 \%)$ of pure $8 .{ }^{1} \mathrm{H}$ NMR $\left(400 \mathrm{MHz}, \mathrm{CDCl}_{3}\right) \delta 7.60(\mathrm{~m}, 4 \mathrm{H}), 7.38$ (m, 4H), $7.29(\mathrm{~m}, 2 \mathrm{H}), 7.25(\mathrm{~d}, 1 \mathrm{H}), 7.18(\mathrm{~d}, 2 \mathrm{H}), 7.15(\mathrm{~s}, 1 \mathrm{H}), 6.99(\mathrm{~m}, 2 \mathrm{H}), 6.93(\mathrm{~m}, 2 \mathrm{H}), 6.88$ $(\mathrm{m}, 1 \mathrm{H}), 6.51(\mathrm{~s}, 1 \mathrm{H}), 4.24(\mathrm{~s}, 2 \mathrm{H}), 3.76(\mathrm{~s}, 3 \mathrm{H}), 3.60(\mathrm{~s}, 3 \mathrm{H}), 2.31(\mathrm{~s}, 2 \mathrm{H}),{ }^{13} \mathrm{C}$ NMR $(100 \mathrm{MHz}$, $\left.\mathrm{CDCl}_{3}\right) \delta 149.88,147.21,144.61,143.33,143.27,143.03,142.56,140.91,136.83,136.49$, 136.26, 136.05, 135.25, 134.25, 133.95, 131.61, 128.90, 128.88, 127.59, 127.53, 125.95, 125.79, 125.56, 125.51, 124.55, 124.27, 123.80, 123.68, 123.47, 111.89, 69.68, 61.64, 56.10, 48.07, 46.81; HRMS (ESI) calcd for $\mathrm{C}_{41} \mathrm{H}_{30} \mathrm{O}_{2} \mathrm{~S}_{4}$ : 682.1129. Found: 682.1127 [M] $]^{+}$ 
Polymerization of monomer (8). To a solution of $8(100 \mathrm{mg}, 0.146 \mathrm{mmol})$ in dry and deoxygenated $\mathrm{CH}_{2} \mathrm{Cl}_{2}(2 \mathrm{ml})$ was added a solution of bis(tricyclohexylphosphine)benzylideneruthenium(IV) dichloride $(1.2 \mathrm{mg}, 0.00146 \mathrm{mmol})$ in $\mathrm{CH}_{2} \mathrm{Cl}_{2}$ (1 ml) through a cannula. After stirring at room temperature for $22 \mathrm{~h}$, excess ethyl vinyl ether was added, and the mixture was stirred for an additional $30 \mathrm{~min}$, and during which time a precipitate had formed. The resulting solid was filtered, washed with ether, and dried to afford polymer 9 in $83 \%$ yield. ${ }^{1}{ }^{1} \mathrm{H}$ NMR (400 MHz, $\mathrm{CDCl}_{3}$ ) $\delta$ 7.31-6.50 (m, 18H), 5.59 (br, 2H), 4.20 (br, 2H), 3.38 (br, 6H), 2.50 (br, 2H). 


\section{Reference}

(1) John, T. P; Eric, G. R. J. Chem. Soc., Perkin Trans. 1, 1988, 8, 2415.

(2) Banzatti, C.; Carfagna, N.; Commisso, R.; Heidempergher, F.; Pegrassi, L.; Melloni, P. J. Med. Chem. 1988, 31, 1466.

\section{Thermogravimetric Analysis Scan.}

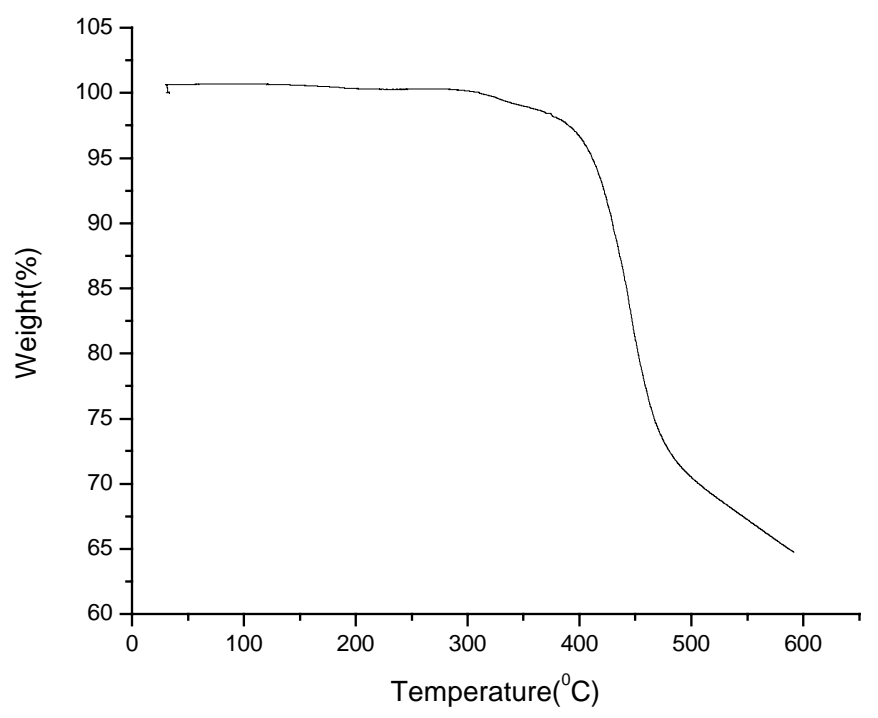

Figure S1. TGA scan of polymer 9 under a nitrogen atmosphere at a heating rate of $10^{\circ} \mathrm{C} / \mathrm{min}$. 


\section{Photophysical Properties Monomer (8) and Polymer (9) in $\mathrm{CHCl}_{3}$ Solution.}
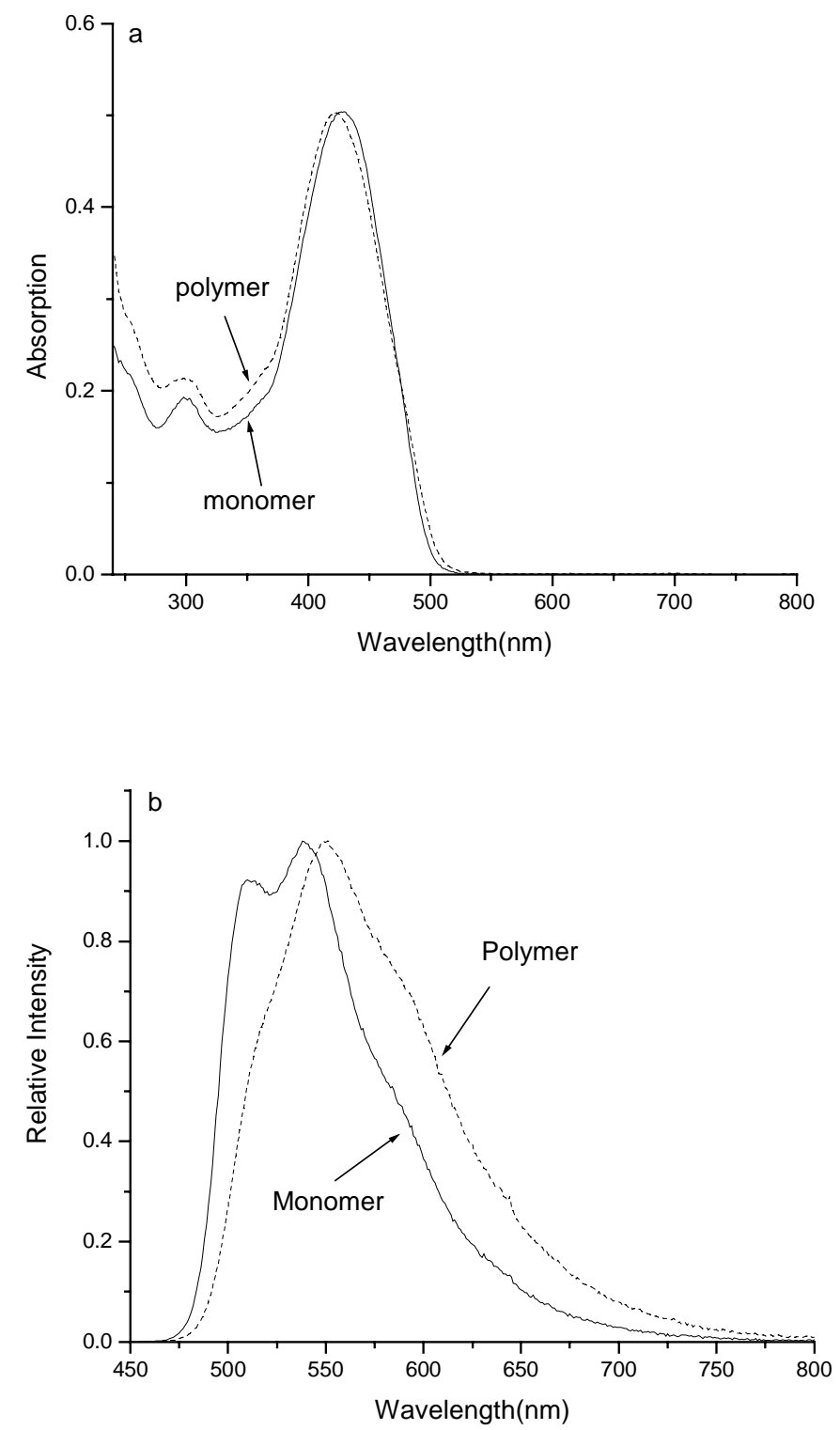

Figure S2. (a) The UV-Vis absorption of monomer $\mathbf{8}\left(c=2.9 \times 10^{-4} \mathrm{M}\right)$ and polymer $\mathbf{9}(c=0.21$ $\mathrm{mg} / \mathrm{ml}$ ) in $\mathrm{CHCl}_{3}$ solution. (b) The emission spectra of monomer 8 and polymer 9 in $\mathrm{CHCl}_{3}$ solution. 


\section{Gel Permeation Chromatogram of Polymer 9}

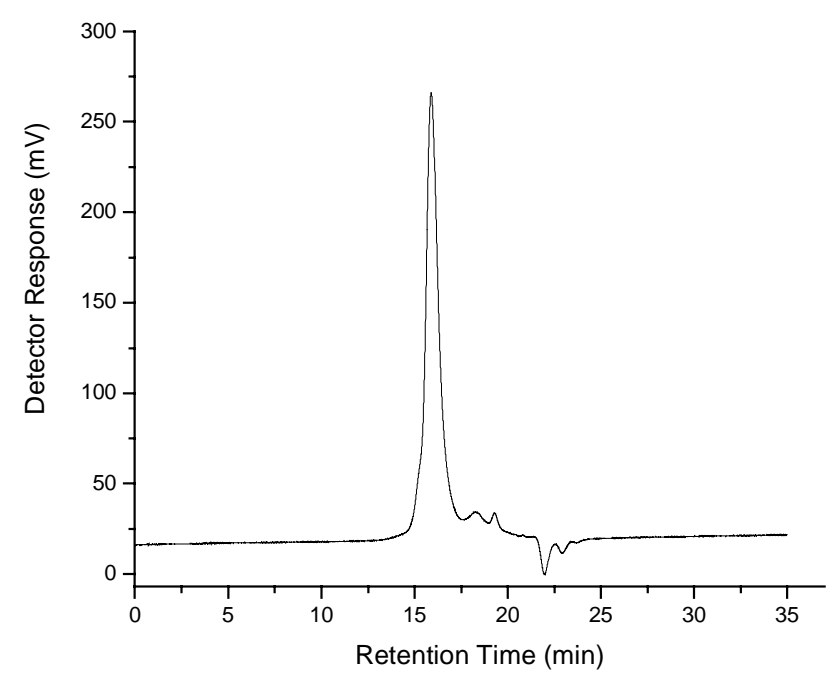

Figure S3. Gel permeation chromatogram of polymer $9\left(M_{\mathrm{w}}=70434, M_{\mathrm{n}}=65,217, P D I=1.08\right)$.

\section{Cyclic Voltammogram of Polymer 9}

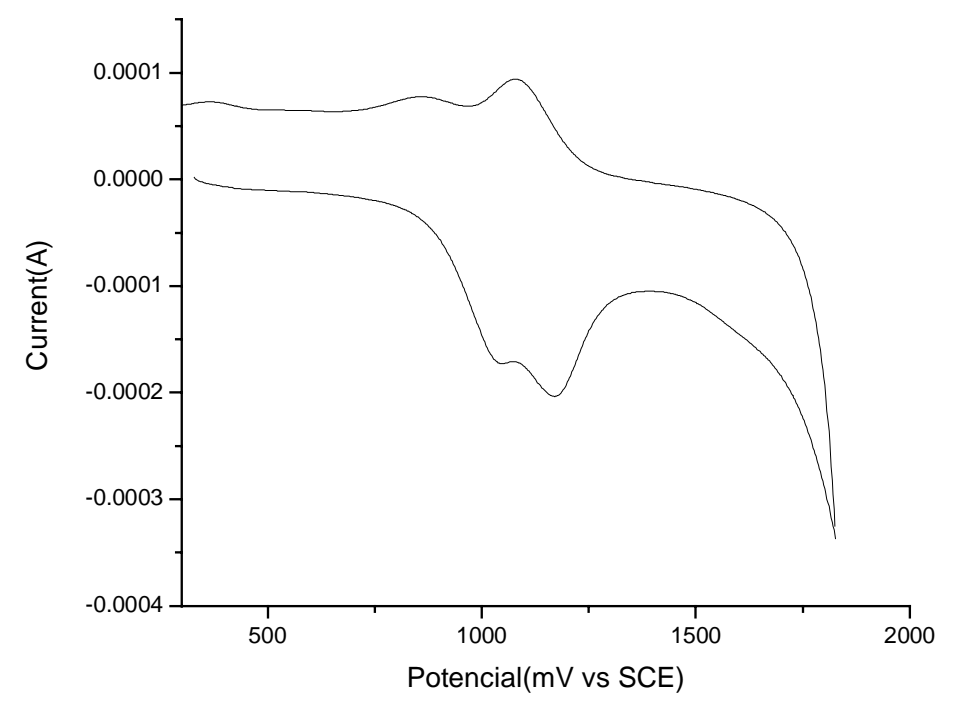

Figure S4. Cyclic voltammogram of polymer 9 in a mixture of $\mathrm{CHCl}_{3} / \mathrm{CH}_{3} \mathrm{CN}(1: 1 \mathrm{v} / \mathrm{v})$ solution containing $\mathrm{Bu}_{4} \mathrm{NPF}_{6}(0.1 \mathrm{M})$ at room temperature, with a scanning rate $100 \mathrm{mV} / \mathrm{s}$. Potentials are versus saturated calomel electrode (SCE) and were externally calibrated by the ferrocene 
/ferrocenium couple $\left(\mathrm{Fc} / \mathrm{Fc}^{+}\right)$. Working electrode: $\mathrm{Pt}$ wire; counter electrode: $\mathrm{Pt}$ wire; reference electrode: $\mathrm{Ag}$ wire/ $\mathrm{AgNO}_{3}$. 